\title{
Development of an LH receptor assay capable of measuring serum LH/CG in a wide variety of species
}

\author{
N. Selvaraj and N. R. Moudgal* \\ Department of Biochemistry and Center for Reproductive Biology and Molecular Endocrinology, \\ Indian Institute of Science, Bangalore 560 012, India
}

\begin{abstract}
The development of a radioreceptor assay (RRA) that can measure serum $\mathrm{LH}$ in a variety of species and CG in sera and urine of pregnant women and monkeys is reported. Using sheep luteal membrane as the receptor source and ${ }^{125}$ I-labelled hLH/hCG as the tracer, doseresponse (displacement) curves were obtained using hLH or hCG as standard. The addition of LH-free serum ( $200 \mu \mathrm{l}$ per tube) had no affect on the standard displacement curve. The assay is simple, requires less than $90 \mathrm{~min}$ to complete and provides reproducible results. The sensitivity of the assay was $0.6 \mathrm{ng} \mathrm{hLH}$ per tube and the intra- and interassay variations were 9.6 and 9.8, respectively. Sera obtained from male and female bonnet monkeys (Macaca radiata) and monkey pituitary extract showed parallelism to the standard curve. The concentrations of LH measured correlated with the physiological status of the animals. Sera of rats, rabbits, hamsters, guinea-pigs, sheep and humans showed parallelism to the hLH standard curve indicating the viability of the RRA to measure serum LH of different species. Since the receptors recognize $\mathrm{LH}$ and $\mathrm{CG}$, detection of pregnancy in monkeys and women was possible using this assay. The sensitivity of the assay for hCG was $8.7 \mathrm{miu}$ per tube. This RRA could be a convenient alternative to the Leydig cell bioassay for obtaining the LH bioactivity profile of sera and biological fluids.
\end{abstract}

\section{Introduction}

Currently, the method of choice for measuring serum LH is the radioimmunoassay (RIA). The major drawbacks of the RIA are that the antibody and ligand have to be carefully chosen to ensure specificity and an RIA developed for one species may not be suitable for another. In addition, the bio:immuno activity ratio is sometimes greater than 1.0, suggesting that the RIA is not measuring some forms of active hormones in circulation (Sakai and Channing, 1979). Whereas the mouse/rat Leydig cell assay (Dufau et al., 1977; Neill et al., 1977; Puri et al., 1980) may be used to monitor bioactivity of serum $\mathrm{LH}$, problems limit its routine use. In addition, in the in vitro steroidogenic assay, the presence of extraneous serum factors has been observed to influence the results (Ascoli et al., 1987; Calkins et al., 1988; Yan et al., 1988). Radioreceptor assays (RRAs) have been developed in the past but their applicability has been limited because of interference from serum (Sakai and Channing, 1979). During our studies on LH receptors, it was observed that the receptor preparation obtained from ovine luteal tissue could be used for the development of an RRA that could measure serum LH. Although our initial interest was to measure serum LH in macaque monkeys, it was found that the RRA could be used to measure LH in humans and some laboratory species. We, therefore, report here the development of an LH RRA of universal application.

*Corresponding author.

Received 15 December 1992.

\section{Materials and Methods}

\section{Source and preparation of receptor}

Sheep ovaries obtained from the local abattoir were kept on ice and dissected out carefully. The corpora lutea separated from the ovary were homogenized in a blender at $4{ }^{\circ} \mathrm{C}$ in Tris-

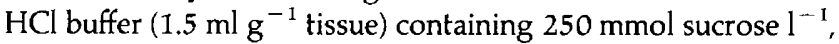
$1 \mathrm{mmol}$ phenylmethylsulfonyl fluoride (PMSF) $\mathrm{I}^{-1}$ and $\mathrm{I} \mathrm{mmol}$ chicken egg white trypsin inhibitor $1^{-1}(\mathrm{pH} 7.4$, buffer A). The homogenate was centrifuged at $30000 \mathrm{~g}$ in a Sorvall refrigerated centrifuge (RC5B) at $4{ }^{\circ} \mathrm{C}$ for $30 \mathrm{~min}$ using an $\mathrm{SS} 34$ rotor. The pellet was washed in Tris- $\mathrm{HCl}$ buffer containing $10 \mathrm{mmol}$ $\mathrm{MgCl}_{2} \mathrm{l}^{-1}$ and $0.1 \% \mathrm{BSA}$ ( $\mathrm{pH} 7.4$, buffer $\mathrm{B}$ ) and resuspended in buffer $B\left(1.2 \mathrm{ml} \mathrm{g}^{-1}\right.$ tissue), divided into aliquots and stored at $-70^{\circ} \mathrm{C}$ until needed.

\section{Chemicals, hormones and iodination procedure}

Tris, PMSF, chicken egg white trypsin inhibitor, BSA, diaminohexane and glutaraldehyde were obtained from Sigma Chemicals (St Louis, MO) and Sepharose $4 \mathrm{~B}$ for the affinity matrix was from Pharmacia Fine Chemicals (Uppsala). Iodogen was supplied by Pierce Chemical Company (Rockford, IL). All other chemicals were of Analar grade obtained from local suppliers. Carrier-free ${ }^{125} \mathrm{I}-\mathrm{Na}$ was obtained from Amersham (UK). Human LH (NIH AFP-4745B), rabbit LH (NIH AFP-7848), PMSG and hCG (CR123) were gifts from G. Bialy (NIAMDD, USA). Buffalo LH (KM-1-192 P-2) was provided by Professor 
Muralidhar (Delhi University, Delhi). Ovine LH used for affinity matrix was a laboratory preparation ( $1 \mathrm{ng}$ is equivalent to $0.133 \mathrm{ng}$ hLH AFP4745B). Iodination of hLH and hCG was carried out according to the method of Fraker and Speck (1978). Briefly, the hormone $(10 \mu \mathrm{g}$ in $20 \mu \mathrm{l})$ was exposed to ${ }^{125} \mathrm{I}-\mathrm{Na}$ $(0.5 \mathrm{mCi})$ in iodogen-coated tubes $\left(5 \mu \mathrm{g} 300 \mu \mathrm{l}^{-1}\right)$ for $1 \mathrm{~min}$ on ice and the mixture loaded on a Sephadex G-50 column $(1 \mathrm{~cm} \times$ $20 \mathrm{~cm}$ ) to separate the free ${ }^{125} \mathrm{I}-\mathrm{Na}$ from iodinated hormone.

\section{Preparation of LH-free serum}

Since LH antibodies generated to ovine-LH (oLH) in monkeys are known to neutralize endogenous monkey LH (Prahalada et al., 1975) an antiserum to oLH raised in a bonnet monkey was used as an LH-free serum. The excess of LH antibody that can interfere in the LH RRA was removed by passing the antiserum through an oLH affinity matrix according to the procedure described by Murthy and Moudgal (1986). The affinity matrix ( $1 \mathrm{ml}$ containing $3.6 \mathrm{mg}$ oLH was added to $6 \mathrm{ml}$ of monkey antiserum to oLH) and the suspension was shaken overnight at $4^{\circ} \mathrm{C}$ in an end-to-end shaker. It was then centrifuged at $200 \mathrm{~g}$ for $5 \mathrm{~min}$ and the supernatant separated. Since free antibodies against oLH bind to the LH affinity matrix, the supernatant did not contain either LH antibodies or LH. This LH-free serum was used to check for serum effect in the assay.

\section{Assay procedure}

An aliquot of the frozen receptor was thawed and homogenized using a Teflon-coated pestle in a motor-driven homogenizer. The RRA was carried out in $10 \mathrm{~mm} \times 65 \mathrm{~mm}$ high density polyethylene (HDPE) tubes. Buffer B $350 \mu \mathrm{l}$ and receptor $50 \mu \mathrm{l}$, containing $80-100 \mu \mathrm{g}$ protein were added to $100 \mu \mathrm{l}$ of the standard $(0.20-25 \mathrm{ng}$ hLH) or unknown. Nonspecific binding was determined in the presence of excess cold hormone (100 ng). Generally, the receptor suspension was added with an Eppendorff repeater and the time taken for the addition of the receptor was less than $1 \mathrm{~min}$. The contents of the assay tubes were mixed well by vortexing and preincubated at $37^{\circ} \mathrm{C}$ for $15 \mathrm{~min}$ in a Dubnoff shaker (approximately 60 oscillations $\left.\min ^{-1}\right)$ before the addition of ${ }^{125}$ I-labelled hLH $(100 \mu \mathrm{l}$, approximately 120000 c.p.m.), and incubation continued for a further $40 \mathrm{~min}$. One millilitre of ice-cold buffer B was added to each tube which was then centrifuged at $1600 \mathrm{~g}$ for $20 \mathrm{~min}$. The supernatant was discarded and the pellet washed with $1 \mathrm{ml}$ buffer $B$ and recentrifuged at $1600 \mathrm{~g}$ for $20 \mathrm{~min}$. The pellet was counted for radioactivity in an LKB multigamma counter. The total time required for the assay was less than $2 \mathrm{~h}$.

\section{Radioimmunoassay}

A solid phase radioimmunoassay to measure human $\mathrm{LH} / \mathrm{CG}$ and monkey CG was carried out as described by Murthy et al. (1989). Briefly, HDPE tubes, precoated with an immunochemical bridge were coated with the appropriate dilution of rabbit antibody to oLH $\beta$ and used for the solid-phase assays. The standard or $200 \mu \mathrm{l}$ serum or urine was added to the coated HDPE tubes followed by the addition of ${ }^{125}$ I-labelled hLH (approximately 100000 c.p.m.) and the volume made up to $0.6 \mathrm{ml}$ with
$0.05 \mathrm{~mol}$ phosphate buffer $\mathrm{l}^{-1}$ containing $0.025 \mathrm{~mol} \mathrm{EDTA}^{-1}$, $0.9 \% \mathrm{NaCl}$ and $1 \%$ bovine serum, $\mathrm{pH} 7.4$ (RIA buffer). The assay mixture was incubated at room temperature overnight, the liquid content removed and the assay tubes washed with $0.6 \mathrm{ml}$ RIA buffer and counted in an LKB multigamma counter. The oLH $\beta$ antibody used has been shown to crossreact with human CG and LH (present study) and monkey CG but not with monkey LH (Rao et al., 1984).

\section{Statistical analysis}

Data were analysed with a four parameter logistic RIA program developed by Rodbard et al. (1978). This program takes into account the nonspecific as well as specific binding and the amount of radioactivity bound in the presence of different concentrations of unlabelled hormone and gives the best fitting standard curve. It also calculates the concentration of unlabelled hormone required for $50 \%$ displacement of the tracer bound to the receptor $\left(\mathrm{EC}_{50}\right)$ with $95 \%$ confidence limit and the slope of the standard curve. In addition, where necessary, differences between groups and values were analysed by Student's $t$ test for significance.

\section{Results}

Effect of LH-free serum on the binding of ${ }^{125}$ I-labelled hCG to LH receptor preparation

The LH antiserum passed through the LH affinity matrix failed to bind ${ }^{125}$ I-labelled hCG indicating that the serum was free of LH antibody that could interfere in the RRA (data not shown). LH-free serum $(200 \mu \mathrm{l}$ per tube) had no effect on the binding of ${ }^{125}$ I-labelled hCG to the receptor (8304 \pm 451 c.p.m. versus $8561 \pm 672$ c.p.m.) indicating that the serum was free of $\mathrm{LH}$. To confirm the lack of interference of serum in the assay, a displacement analysis of ${ }^{125}$ I-labelled hCG binding to the receptor was carried out after adding different concentrations of LH-free serum $(200 \mu \mathrm{l})$ to the standard. The displacement curves obtained were indistinguishable from one another (Fig. 1) confirming the lack of interference of serum factors in the RRA.

\section{Characteristics of the standardized $R R A$}

Human LH was used as radioligand and standard since it is available in a high state of purity and is easy to iodinate. The assay sensitivity ( $0.6 \mathrm{ng}$ per tube) and range (0.6-10 ng per tube) were dependent on receptor concentration; use of 80 $100 \mu \mathrm{g}$ receptor protein per tube gave maximal sensitivity (Fig. 2). The intra- and interassay coefficients of variation obtained using male monkey serum were $9.6 \%$ and $9.8 \%$, respectively. It was possible to analyse sera containing as little as $3 \mathrm{ng} \mathrm{LH} \mathrm{ml} \mathrm{m}^{-1}$ using this assay. The amount of standard hormone required for $50 \%$ displacement of the radioactive label binding to the receptor $\left(\mathrm{EC}_{50}\right)$ was $2.14 \pm 0.21 \mathrm{ng}$. The displacement values with different volumes of sera were also analysed by computer to obtain the volume of serum required for $50 \%$ displacement. $\mathrm{LH}$ concentrations in this volume were 


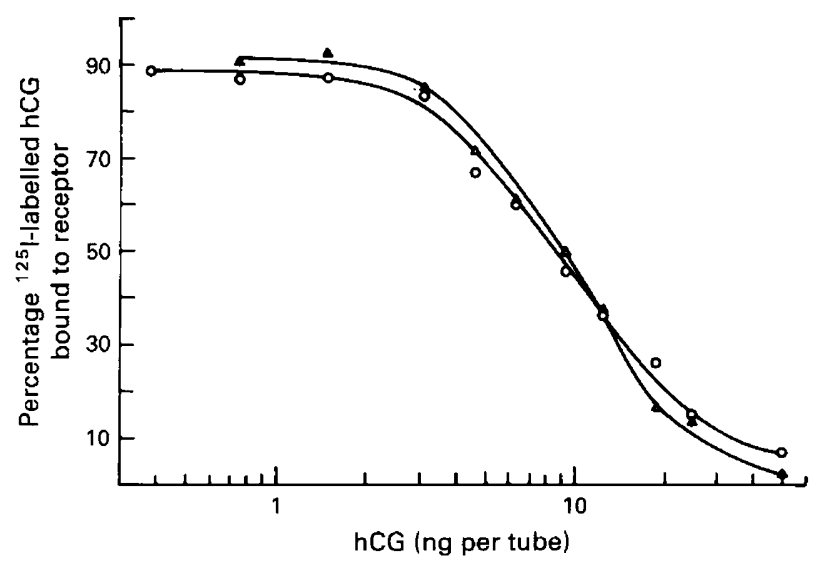

Fig. 1. Effect of addition of LH-free serum on the hCG/LH standard displacement curve. (O) hCG standard curve; $(\Delta)$ standard with $200 \mu \mathrm{l} \mathrm{LH}$-free serum added.

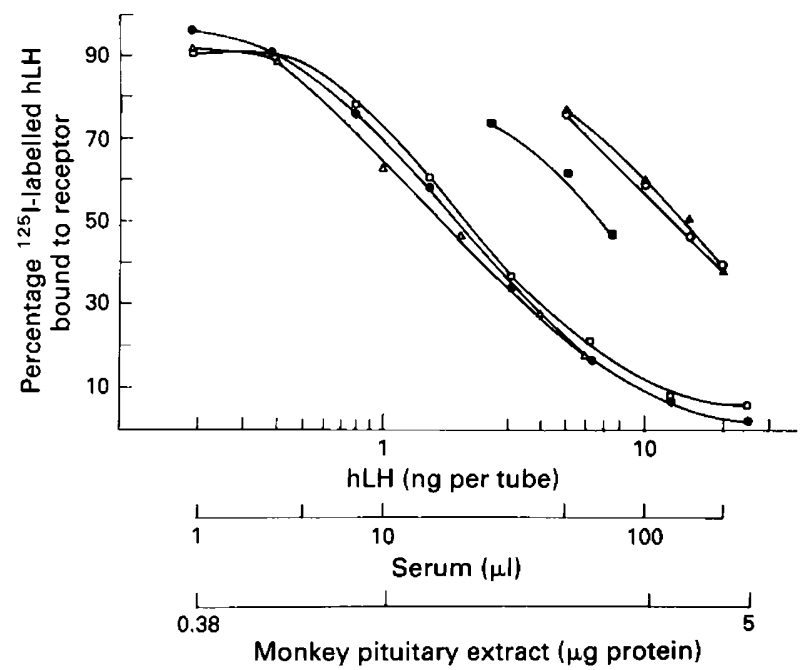

Fig. 2. Demonstration of parallelism of the displacement curves in the $\mathrm{LH}$ radioreceptor assay using sera and pituitary extract from monkeys. (O) hLH standard, $(\triangle)$ serum from periovulatory phase, $(O)$ serum from luteal phase, ( $\boldsymbol{D})$ serum from castrated adult male, ( $\mathbf{\Delta})$ serum from intact adult male, $(\square)$ monkey pituitary extract. For details of methodology refer to text.

measured from the standard graph giving an $\mathrm{EC}_{50}$ value for serum of $1.98 \pm 0.14 \mathrm{ng}$.

\section{Measurement of $L H$ from sera of different species}

Sera from the hamsters, rats, guinea-pigs, rabbits, sheep, monkeys (all males) and women showed parallelism to the standard displacement curve obtained using hLH as tracer and standard (Fig. 3) indicating that this assay could be used for LH measurement in a variety of species. The crossreactivity of purified $\mathrm{LH}$ preparation of various species was checked in routine LH RRA using hLH as the radioligand and standard. The $\mathrm{EC}_{50}$ values for hLH, hCG, rabbit LH, oLH, PMSG and buffalo LH were 2.14, 1.4, 9.7, 16.0, 21.0 and $55.0 \mathrm{ng}$ per tube, respectively.

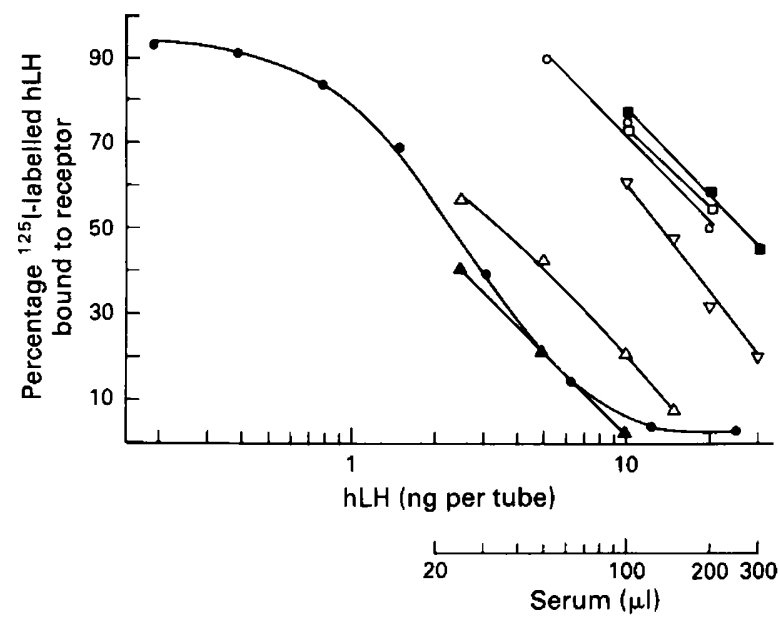

Fig. 3. Applicability of $\mathrm{LH}$ radioreceptor assay to measure $\mathrm{LH}$ in serum from a variety of species. $(\mathbf{O}) \mathrm{hLH}$ standard, $(\boldsymbol{\Delta})$ rat serum, $(\Delta)$ rabbit serum, $(\nabla)$ sheep serum, $(\bigcirc)$ human serum, $(\square)$ hamster serum, $(\square)$ guinea-pig serum. All samples were from adult males, except in humans where samples from women were used. For details of methodology refer to text.

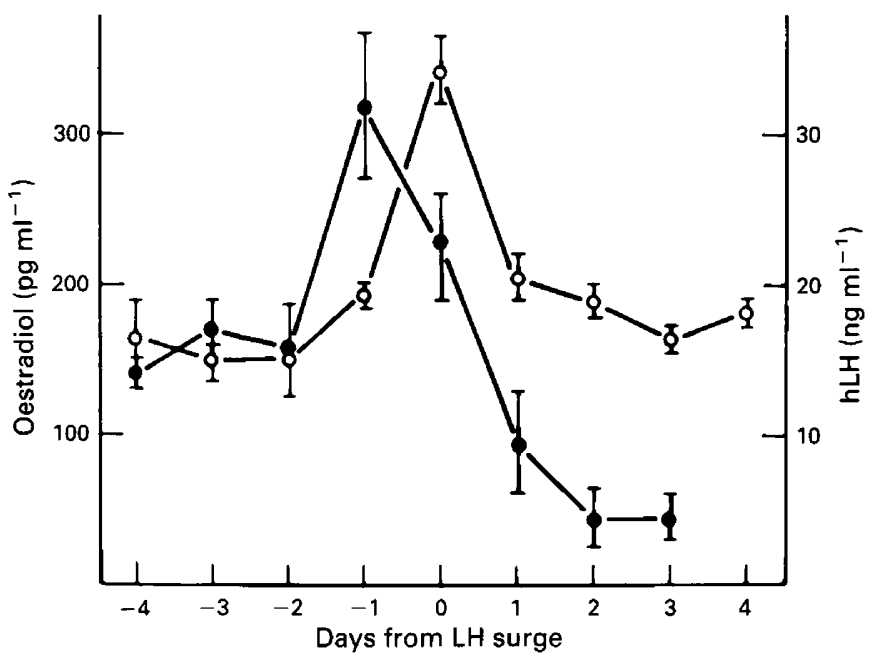

Fig. 4. $\mathrm{LH}$ and oestradiol profiles in serum from female bonnet monkeys during the periovulatory phase $(n=7)$ mean $\pm \mathrm{SD}$. (O) $\mathrm{LH}$ and $(\mathbf{O})$ oestradiol.

Application of the assay to measure serum $L H$ in bonnet monkeys in different physiological states

Sera from animals with different physiological status and a pituitary extract from bonnet monkeys showed parallelism to the standard (Fig. 2). Their positioning, with respect to the standard, however, changed depending on LH concentration. In intact female monkeys, the maximal concentration of LH is in the peri-ovulatory phase (days 10 to 12 of cycle, $50.64 \pm$ $6.2 \mathrm{ng}$ hLH equivalent $\mathrm{ml}^{-1}, n=20$ ); however, basal concentrations of $\mathrm{LH}$ were exhibited during the early follicular (days 1 to 8 of cycle, $24.02 \pm 9.4 \mathrm{ng} \mathrm{hLH}$ equivalent $\mathrm{ml}^{-1}, n=33$ ) and luteal phase (days 14 to 28 of cycle, $23.5 \pm 10.27 \mathrm{ng} \mathrm{hLH}$ equivalent $\mathrm{ml}^{-1}, n=30$ ) of the cycle. Gonadectomized monkeys 


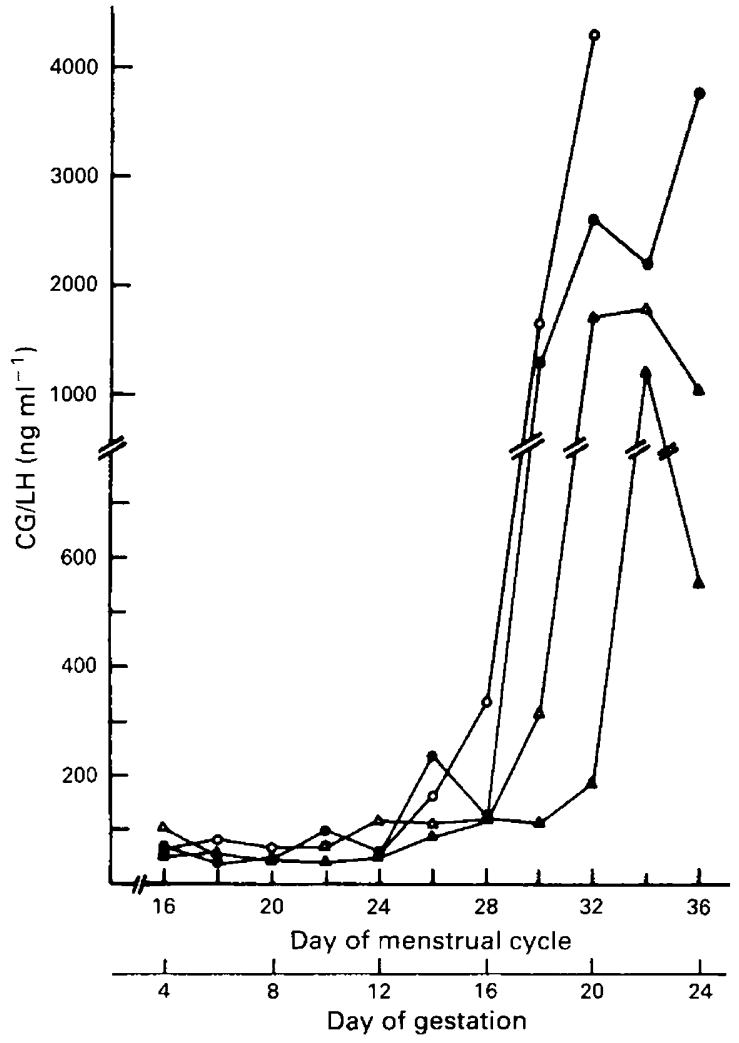

Fig. 5. Individual measurements of serum $\mathrm{CG} / \mathrm{LH}$ during the luteal phase in the fertile cycle of four bonnet monkeys. Day of ovulation was considered as day $I$ of gestation. For details of methodology refer to text.

Table 1. Comparison of human serum and urinary LH/CG as measured by radioreceptor assay (RRA) and radioimmunoassay (RIA)

\begin{tabular}{lcrr}
\hline & & \multicolumn{2}{c}{ LH/CG $\left(\mathrm{ng} \mathrm{ml}^{-1}\right)$} \\
\cline { 3 - 4 } Sample & Subject & \multicolumn{1}{c}{ RIA } & RRA \\
\hline \multirow{2}{*}{ Serum } & & & \\
& $\mathrm{A}$ & 10 & 27 \\
& $\mathrm{~B}$ & 11 & 22 \\
& $\mathrm{C}$ & 13 & 21 \\
& $\mathrm{D}$ & 367 & 600 \\
Urine & E & 52000 & 15000 \\
& & & \\
& $\mathrm{~F}$ & 10 & 25.5 \\
& $\mathrm{G}$ & 500 & 78.5 \\
& $\mathrm{H}$ & 10500 & 8200 \\
\hline
\end{tabular}

Pregnancy was confirmed in subjects D, E, H and I.

exhibit $\mathrm{LH}$ concentrations between basal and periovulatory concentrations ( $43.0 \pm 20.0 \mathrm{ng}$ hLH equivalent $\mathrm{ml}^{-1}, n=3$ ). The specificity of the assay was checked by measuring serum $\mathrm{LH}$ in a group $(n=8)$ of $\mathrm{FSH}$-immunized, adult, male bonnet monkeys. The results showed that LH concentrations did not
Table 2. Comparison of CG/LH concentrations in sera from two pregnant monkeys obtained by radioreceptor assay (RRA) and radioimmunoassay (RIA)

\begin{tabular}{lcrrr}
\hline $\begin{array}{l}\text { Day of } \\
\text { menstrual } \\
\text { cycle }\end{array}$ & \multicolumn{4}{c}{ CG/LH $\left(\mathrm{ng} \mathrm{ml}^{-1}\right)$} \\
\cline { 2 - 4 } & RIA & RRA & RIA & RRA \\
\hline 20 & ND & 65 & ND & 33 \\
22 & ND & 62 & ND & 16 \\
24 & ND & 67 & ND & 37 \\
26 & ND & 160 & ND & 122 \\
28 & 18 & 335 & 18 & 245 \\
30 & 50 & 1650 & 40 & 1370 \\
32 & 96 & 4300 & 106 & 2375 \\
34 & - & - & 152 & 3300 \\
36 & - & - & 112 & 3275 \\
\hline
\end{tabular}

ND: Not detected.

differ significantly from the untreated controls $(n=3$; controls: $17.50 \pm 0.5$ versus $\mathrm{FSH}$-immunized: $13.2 \pm 2.3 \mathrm{ng} \mathrm{hLH}$ equivalent $\mathrm{ml}^{-1}$ ) indicating that the presence of FSH antibody did not interfere with the assay. Serum LH concentrations of female monkeys $(n=7)$ during the follicular phase were measured using this assay and the $\mathrm{LH}$ surge is seen within $24 \mathrm{~h}$ of the oestrogen surge (Fig. 4).

Use of LH RRA to measure CG concentrations and confirm pregnancy in monkeys and humans

Sera from cyclic female monkeys cohabiting with males of proven fertility (between days 9 and 14 of the cycle) were analysed using this assay. In non-mated, cyclic monkeys, serum LH concentrations from day 26 to the end of the cycle were at basal values $\left(23.5 \pm 10.27 \mathrm{ng} \mathrm{hLH}\right.$ equivalent $\left.\mathrm{ml}^{-1}\right)$. Thus a significant increase in LH/CG concentrations between days 26 and 40 of the cycle (day 13 to 27 of gestation) of mated monkeys was used as confirmation of pregnancy (Fig. 5).

The RRA was also used to measure urinary and serum CG and LH concentrations and confirm pregnancy in women who had missed regular menses. The earliest samples obtained were from two women on day 34 of cycle. The CG and LH concentrations of women confirmed pregnant by this test ranged from $200-15000 \mathrm{ng} \mathrm{ml}^{-1}$ of serum and those of non-pregnant women were less than $50 \mathrm{ng} \mathrm{ml}^{-1}$.

\section{Validation of the LH RRA}

Comparative values of LH/CG concentrations of some of the human serum and urine samples measured by LH/CG RRA and RIA are given (Table 1). LH/CG concentrations in sera from the pregnant monkeys estimated using the RRA and the solid phase RIA are also given (Table 2).

The validity of the RRA assay was also checked by assaying LH in sera of a castrated and an intact monkey using the mouse Leydig cell bioassay as described by Van Damme et al. (1974). The values obtained by the bioassay were 200 and $13 \mathrm{ng} \mathrm{ml}^{-1}$ 
for the castrated and the normal sera, respectively. The corresponding values obtained by RRA were 74 and $22 \mathrm{ng} \mathrm{ml}^{-1}$, respectively.

\section{Discussion}

The binding of $\mathrm{LH}$ to its receptor is the first event in the expression of hormonal activity; a radioreceptor assay should therefore provide a true assessment of LH bioactivity. Several attempts have been made to develop a viable LH RRA using different receptor preparations and manipulative procedures; for example, a rat testicular preparation (Catt et al., 1972); a luteal cell preparation from pregnant cows (Saxena et al., 1974), from which a commercial kit was developed (Booher et al., 1983); a porcine granulosa cell preparation (Sakai and Channing, 1979) and a membrane preparation of cultured MA-10 Leydig tumour cells (Whitcomb and Scheyer, 1990). While some of the earlier procedures were time consuming and had problems of serum interference, the bovine luteal cell preparation (Landesman and Saxena, 1976) and the Leydig tumour cell preparation have been used to measure serum LH/CG with some degree of success. While the MA-10 Leydig tumour cell membrane-based RRA is slightly more sensitive than our procedure, it is more time consuming and expensive since the membrane preparation has to be isolated from cultured tumour cells and the assay requires $24 \mathrm{~h}$ incubation and centrifugation at $30000 \mathrm{~g}$ for $15 \mathrm{~min}$ to separate the bound hormone from the free. The assay based on the bovine luteal membrane has been used primarily to detect pregnancy and its ability to measure serum $\mathrm{LH}$ has not been validated. In addition, the amount of serum/plasma required for assay of CG using the bovine luteal membrane preparation is 10-20 times higher than that used in our assay. The current assay may also be used to measure $\mathrm{CG} / \mathrm{LH}$ in urine and serum samples of primates.

Our assay is cost effective in that it is not dependent on expensive antibodies; the source of the receptor, ovine luteal tissue, is readily available from abattoirs, and the receptor preparation retains its bioactivity when stored in a lyophilized state for several months (data not shown). The ovine luteal LH receptor is specific to $\mathrm{LH}$; neither FSH nor TSH (up to $100 \mathrm{ng}$ per tube) are able to displace the radiolabelled hormone bound to the receptor. The assay results are amenable to statistical analysis by routinely used RIA software. The computergenerated profile of the displacement curve of ${ }^{125} \mathrm{I}-\mathrm{hLH}$ binding to the receptor by the hLH standard and the monkey serum is identical, confirming the lack of interference of serum factors in the assay; this is in contrast to the Leydig cell-based bioassay which is known to be influenced by growth factors (Ascoli et al., 1987). The validity of the RRA has been confirmed by comparing the RRA results with those obtained by a routine radioimmunoassay as well as a bioassay. The RRA appeared more sensitive than the RIA for measuring CG concentrations in pregnant human serum and urine, and monkey serum samples. However, while the RIA can detect the $\beta$ subunit and the intact hormone, the RRA can monitor only the intact hormone. This explains why in pregnancies of more than 7 weeks, concentrations measured by the RIA are higher than those measured by the RRA. CG was detected in sera of monkeys using RRA by day 26 of the menstrual cycle. This is in agreement with the results of Rao et al. (1984) who detected CG by day 28 of the cycle using RIA. Although LH values obtained for serum from intact monkeys by RRA and bioassay correlated well, the bioassay value for serum from castrated monkeys was almost three times higher than the RRA value. This may be due to the presence of factors in serum that promote LH responsiveness.

Since LH and CG are equally capable of binding to the receptor, the same assay can be used to detect the mid-cycle LH surge as well as the increase in CG secretion due to pregnancy. The two events can be distinguished as the midcycle LH surge does not extend beyond a two-day period, whereas CG secretion progressively increases in early pregnancy. No false interpretations have been encountered when applying the assay to detect pregnancy in women $(n=160)$ or monkeys $(n=25)$. The present assay is more sensitive than the bovine luteal receptor assay used by Booher et al. (1983) to detect pregnancy in monkeys, as conception could be detected only by days 1720 of gestation compared with days 13-15 of gestation (days 26-28 of menstrual cycle) by our assay.

It is of particular interest that this RRA can be effectively used to measure serum LH in a variety of routinely used laboratory animals. It should be possible using this assay to obtain relative, but comparable, values for $\mathrm{LH}$ production and secretion using a single source of receptor and the same hormone for standard and ligand preparation in different species under similar physiological situations. The feasibility of developing an ELISA version of the RRA, thus totally avoiding the use of radiolabelled $\mathrm{LH}$ as the ligand is currently being examined.

The authors wish to express their gratitude to the Indian Council of Medical Research for financial assistance and to R. R. Devi, Health Center, Indian Institute of Science for providing the clinical samples.

\section{References}

Ascoli M, Euffa J and Segaloff DL (1987) Epidermal growth factor activates steroid biosynthesis in cultured Leydig tumor cells without affecting the levels in CAMP and potentiates the activation of steroid biosynthesis by chorionic gonadotrophin and cAMP Journal of Biological Chemistry 262 9196-9203

Booher CB, Prahalada S and Hendrickx AG (1983) Use of a radioreceptor assay for human luteinizing hormone/chorionic gonadotropin for detection of early pregnancy and estimation of time of ovulation in macaques American Joumal of Primatology 4 45-53

Calkins JH, Sigel MM and Lin T (1988) Modulation of Leydig cell steroidogenesis by recombinant interleukin-1 70th Meeting of the Endocrine Society, New Orleans, LA. Abstract 489

Catt KJ, Dufau ML and Tsuruhara T (1972) Radioligand-receptor assay of luteinizing hormone and chorionic gonadotropin Journal of Clinical Endocrinology and Metabolism 346 123-132

Dufau ML, Hodgen GD, Goodman AL and Catt KJ (1977) Bioassay of circulating luteinizing hormone in the rhesus monkey. Comparison with radioimmunoassay during physiological changes Endocrinology 100 1557-1565

Fraker PJ and Speck JC (1978) Protein and cell membrane iodination with sparingly soluble chloramide 1,3,4,6-tetrachloro-3,6-diphenylglycouril Biochemical and Biophysical Research Communications 80 849-857

Landesman R and Saxena BB (1976) Results of the first 1000 radioreceptor assays for the determination of human chorionic gonadotropin: a new, rapid, reliable and sensitive pregnancy test Fertility and Sterility 27 357-368

Murthy GS and Moudgal NR (1986) Use of epoxysepharose for protein immobilization Joumal of Biosciences $10351-358$

Murthy GS, Lakshmi BS and Moudgal NR (1989) Radioimmunoassay of polypeptide hormones using immunochemically coated plastic tubes journal of Biosciences 14(1) 9-20 
Neill JD, Dailey RA, Tsou RC and Reichert Jr LE (1977) Immunoreactive LH like substances in serum of hypophysectomized and prepubertal monkeys: inactive in an in vitro LH bioassay Endocrinology 100 856-861

Prahalada S, Venkaramiah M, Jagannadha Rao A and Moudgal NR (1975) Termination of pregnancy in macaques $(M$. radiata) using monkey antisenum to ovine luteinizing hormone Contraception 12 137-147

Puri CP, Puri V and Anandkumar TC (1980) Bioactive luteinizing hormone in the plasma and cerebrospinal fluid of female rhesus monkeys Journal of Medical Primatology 9 39-49

Rao AJ, Kotagi SG and Moudgal NR (1984) Serum concentration of chorionic gonadotrophin, oestradiol $17 \boldsymbol{\beta}$ and progesterone during early pregnancy in the south Indian bonnet monkeys (Macaca radiata) Journal of Reproduction and Fertility 70 449-455

Rodbard D, Munson RJ and DeLean A (1978) Improved curve-fitting, paralielism testing, characterization of sensitivity and specificity, validation and optimization for radioligand assays. In Radioimmunoassay and Related Procedures in Medicine Vol 1 pp 469-504. International Atomic Agency, Vienna
Sakai CN and Channing CP (1979) Evidence for alterations in luteinizing hormone secreted in rhesus monkeys with normal and inadequate luteal phases using radioreceptor and radioimmunoassay Endocrinology 104 $1217-1225$

Saxena BB, Hasan SH, Haour F and Gollwitzer MS (1974) Radioreceptor assay of human chorionic gonadotropin: detection of early pregnancy Science $\mathbf{1 8 4}$ 793-795

Van Damme MP, Robertson DM and Dickzalusy E (1974) An improved in vitro bioassay method for measuring luteinizing hormone activity using mouse Leydig cell preparation Acta Endocrinologica 77 655-671

Whitcomb RW and Schneyer AL (1990) Development and validation of a radioligand receptor assay for measurement of luteinizing hormone in human serum Joumal of Clinical Endocrinology and Metabolism 71 591-595

Yan D, Gaulin J and Ducharme JR (1988) Effect of growth hormone on steroidogenesis and protein phosphorylation by immature porcine Leydig cells 70 th meeting of the Endocrine Society New Orleans, LA. Abstract 490 